\title{
EFEKTIVITAS MINUMAN KUNYIT ASAM DAN REMPAH JAHE ASAM TERHADAP PENURUNAN SKALA NYERI HAID PRIMER
}

\author{
Rosi Kurnia Sugiharti ${ }^{1}$, Ririn Isma Sundari ${ }^{2}$ \\ ${ }^{1}$ Prodi Kebidanan D3, STIKES Harapan Bangsa Purwokerto, Jawa Tengah \\ ${ }^{2}$ Prodi Keperawatan S1, STIKES Harapan Bangsa Purwokerto, Jawa Tengah \\ Email : Rossy.kurnia@yahoo.com
}

\begin{abstract}
ABSTRAK
Latar Belakang: Masa remaja merupakan masa transisi antara masa anak dan dewasa dimana terjadi pacu tumbuh (growth spurt) sehingga mereka harus menghadapi tekanan emosi dan sosial yang saling bertentangan. Pada masa remaja ini biasanya terjadi nyeri haid primer. Nyeri haid dapat diatasi dengan pemberian terapi nonfarmakologis yaitu minuman rempah jahe asam dan kunyit asam.

Tujuan: Mengetahui efektivitas minuman kunyit asam dan rempah jahe asam terhadap penurunan tingkat nyeri haid primer

Metode: Model penelitian yang digunakan adalah quasi experiment design dengan non randomized control group pre and post tes. Penelitian dilakukan di STIKES Harapan Bangs Purwokerto. Populasi dalam penelitian ini adalah seluruh Mahasiswi yang mengalami nyeri haid dengan jumlah sampel sebanyak 60 responden yang diambil secara purposive sampling. . Analisis data menggunakan uji paire t-test dan independent $t$-tes

Hasil: Hasil penelitian menunjukan ada perbedaan yang signifikan penurunan skala nyeri haid primer sebelum dan setelah minuman kunyit asam $(p<0.01)$. Ada perbedaan yang signifikan penurunan skala nyeri haid primer sebelum dan setelah minuman rempah jahe asam $(p<0.01)$. ada perbedaan efektivitas penerunan skala skala nyeri haid primer antara kelompok yang diberikan minuman kunyit asam dengan kelompok yang diberikan rempah jahe asam $(p<0.01)$.

Kesimpulan: Minuman kunyit asam maupun minuman rempah jahe asam sama-sama dapat menurunkan skala nyeri haid primer, akan tetapi, minuman kunyit asam lebih efektif dalam menurunkan nyeri haid primer dibandingkan rempah jahe asam.
\end{abstract}

Kata Kunci: Minuman Kunyit Asam; Rempah Jahe Asam; Nyeri Haid Primer

\section{PENDAHULUAN}

Masa remaja merupakan masa transisi antara masa anak dan dewasa dimana terjadi pacu tumbuh (Growth spurt), dan relatif belum mencapai tahap kematangan mental dan sosial sehingga mereka harus menghadapi tekanan emosi dan sosial yang saling bertentangan. Menurut WHO, remaja adalah bila anak telah mencapai umur 10-18 tahun (Andira, 2012). Perubahan perkembangan biologis pada masa remaja ditandai dengan keremajaan secara biologi yaitu di mulainya haid. Haid (menstruasi) merupakan proses pengeluaran darah dari uterus disertai serpihan selaput dinding uterus pada wanita dewasa yang terjadi secara periodik
(Maulana, 2009). Pada saat dan sebelum haid (menstruasi), seringkali wanita mengalami rasa tidak nyaman di perut bagian bawahNyeri Haid dibedakan menjadi dua yaitu Nyeri Haid primer dan Nyeri Haid sekunder. Nyeri Haid primer biasanya terjadi dari mulai pertama haid kurang lebih usia 10-15 tahun (menarke) sampai usia 25 tahun. Nyeri pada Nyeri Haid primer lebih dikarenakan kontraksi uterus, sedangkan Nyeri Haid sekunder disebabkan oleh kelainan yang didapat di dalam rongga uterus (Gilly, 2009). Pada masa remaja ini biasanya dismenorea yang dialami adalah dismenorea primer (Aulia, 2009).

Nyeri haid dapat ditangani dengan 
R K Sugiharti, R I Sundari | Efektivitas Minuman Kunyit Asam dan Rempah Jahe Asam Terhadap Penurunan Skala Nyeri Haid Primer

terapi secara farmakologis atau non farmakologis. Terapi secara farmakologis salah satunya dengan pemberian obat-obat analgesik. Obat golongan NSAID (Nonsteroidal Antiinflammatory Drugs) dapat meredakan nyeri ini dengan cara memblok prostaglandin yang menyebabkan nyeri. Pengobatan dengan menggunakan NSAID memiliki efek samping yang berbahaya terhadap sistem tubuh lainnya (nyeri lambung dan resiko kerusakan ginjal) (Gilly, 2009).

Terapi non farmakologis antara lain pengaturan posisi, teknik relaksasi, kompres hangat, olahraga, relaksasi, dan pemberian ramuan herbal. Terapi ramuan herbal dapat dilakukan dengan cara menggunakan obat tradisional yang berasal dari bahan-bahan tanaman. Beberapa bahan tanaman dipercaya dapat mengurangi rasa nyeri. Salah satu tanaman tersebut adalah jahe (Zingibers Officinale Rosc.) dan kunyit berfungsi sebagai analgesik, antipiretik, dan anti inflamasi (Suharmiati, 2006). Jahe dan kunyit dapat digunakan bersama asam jawa untuk meredakan nyeri haid (Widyastuti, 2008). Asam jawa akan lebih dapat ditingkatkan aktivitas antioksidannya apabila di padukan dengan rempah lain (Widyastuti, 2009). Berdasarkan penelitian Kristiani \& Kusumawati, (2016) menyebutkan bahwa ada perbedaan penurunan tingkat nyeri terjadi rata-rata setelah 15 menit setelah minuman kunyit (kunyit asam) dan jahe asam. Hasil dari penelitian tersebut adalah minuman kunyit asam lebih efektif menurunkan nyeri haid dibandingkan jahe asam.

Berdasarkan studi pendahuluan yang diperoleh dari hasil wawancara pada 20 mahasiswi program studi kebidanan STIKES Harapan Bangsa Purwokerto menunjukkan bahwa $45 \%$ mengatakan nyeri ringan, 40 \% nyeri sedang, 15 \% nyeri berat dan masih banyak mahasiswa yang belum mengetahui manfaat minuman rempah jahe asam dan kuyit asam sebagai pereda rasa nyeri saat menstruasi. Mahasiswa sebesar 40 $\%$ tertarik untuk minum minuman kunyit asam dan $60 \%$ tertarik untuk minum minuman jahe asam sebagai pereda nyeri haidnya. Dari permasalahan diatas maka peneliti tertarik untuk melakukan penelitian yang tentang efektifitas minuman kunyit asam dan rempah jahe asam terhadap penurunan skala nyeri haid primer pada mahasiswi kebidanan. Tujuan penelitian ini adalah untuk mengetahui efektifitas minuman kunyit asam dan rempah jahe asam terhadap penurunan nyeri haid primer.

\section{METODE}

Model penelitian yang digunakan adalah quasi experiment design dengan non randomized control group pre and post tes (Sugiyono, 2009). Penelitian dilakukan di STIKES Harapan Bangs Purwokerto. Populasi dalam penelitian ini adalah seluruh Mahasiswi Stikes Harapan Bangsa Program Studi Kebidanan D3 yang mengalami nyeri haid primer. Jumlah sampel dalam penelitian ini sebanyak 60 responden yang masuk kriteria inklusi yang diambil secara purposive sampling (Saryono, 2011).

Penelitian ini menggunakan dua kelompok responden yaitu kelompok yang diberikan minuman kunyit asam dan kelompok yang diberikan minuman jahe asam. Variabel yang diukur adalah skala nyeri haid 
R K Sugiharti, R I Sundari | Efektivitas Minuman Kunyit Asam dan Rempah Jahe Asam Terhadap Penurunan Skala Nyeri Haid Primer

primer, diukur 15 menit sebelum dan setelah dilakukan intervensi. Pengeukuran skala nyeri menggunkan Numerik Rating Scale (Arifin, 2008). Data dia analisis dengan menggunkan uji paire t-test dan independent $t$-tes. (Saryono, 2011).

\section{HASIL}

Rata-rata usia responden adalah 18,8 tahun dengan usia minimum 17 tahun dan maximum 21 tahun. Pada kelompok responden yang diberikan intervensi kunyit asam, rata-rata mengalami nyeri haid primer pada skala $5.53 \pm 2.030$ dan setelah diberikan minuman kunyit asam menurun menjadi $2.93 \pm 1.639$. Hasil analisis menunjukkan ada perbedaan yang signifikan penurunan skala nyeri haid primer sebelum dan setelah minuman kunyit asam $(p<0.01)$ (Tabel 1).

Pada kelompok yang diberikan intervensi jahe asam, rata-rata mengalami nyeri haid primer pada skala $5.23 \pm 1.924$ dan setelah diberikan minuman jahe asam menurun menjadi $2.80 \pm 1.690$. Ada perbedaan yang signifikan penurunan skala nyeri haid primer sebelum dan setelah minuman rempah jahe asam $(p<0.01)$ (Tabel 1$)$.

Hasil analisis perbedaan efektivitas skala nyeri antara kelompok responden yang diberikan minuman kunyit asam dengan kelompok yang diberikan rempah jahe asam menunjukkan ada perbedaan efektivitas penerunan skala skala nyeri haid primer antara kelompok yang diberikan minuman kunyit asam dengan kelompok yang diberikan rempah jahe asam $(p<0.01)$, dimana minuman kunyit asam lebih efektif dalam menurunkan nyeri haid primer dibandingkan rempah jahe asam. (Tabel 2).

\section{PEMBAHASAN}

Rata-rata usia responden dalam penelitian ini adalah 18,8 tahun dengan usia minimum 17 tahun dan maximum 21 tahun. Hal ini sesuai dengan penelitian sebelumnya yaitu penelitian yang dilakukan oleh Novia dan Puspitasari (2008) tentang faktor-faktor yang mempengaruhi kejadian dismenore primer. Penelitian menunjukan bahwa dismenore primer lebih banyak ditemukan pada rentang usia 15-25 tahun dengan persentase $87 \%$ pada jumlah responden 100 orang. Penelitian lainnya oleh Ortiz (2010) menunjukan bahwa rata-rata usia responden yang mengalami dismenore adalah 17-35 tahun. Dismenore primer umumnya dimulai pada 1-3 tahun setelah haid pertama (menarche). Kasus ini bertambah berat beberapa tahun hingga usia 23-27 tahun (Morgan dan Hamilton, 2009).

Pada penelitian ini didapatkan hasil bahwa minuman kunyit asam dan rempah jahe asam sama-sama dapat menurunkan nyeri haid primer pada remaja. Hal ini disebabkan karena pada kunyit asam dan jahe asam terdapat agen aktif yang berfungsi sebagai antiinflamasi, analgesic dan antioksidan. Hasil penelitian sesuai dengan teori yang diungkapkan oleh Hatcher (2008) yang mengatakan bahwa minuman kunyit asam memiliki khasiat dasar sebagai analgetika dan antiinflamasi. Agen aktif dalam kunyit yang berfungsi sebagai antiinflamasi dan antipiretika adalah curcumine, sedangkan sebagai analgetika adalah curcumenol. Buah asam jawa, memiliki agen aktif alami anthocyanin sebagai antiinflamasi dan antipiretika. 
R K Sugiharti, R I Sundari | Efektivitas Minuman Kunyit Asam dan Rempah Jahe Asam Terhadap Penurunan Skala Nyeri Haid Primer

Tabel 1. Perbedaan Skala Nyeri Haid Sebelum dan Sesudah Intervensi pada Kelompok Minuman Kunyit Asam dan Minuman Rempah Jahe Asam

\begin{tabular}{lccccc}
\hline Kelompok & $\mathbf{n}$ & Mean \pm SD & Mean dif & t & p-value \\
\hline $\begin{array}{l}\text { Kunyit Asam } \\
\text { Sebelum }\end{array}$ & 30 & $5.53 \pm 2.030$ & 2.6 & 16.656 & 0.0001 \\
$\quad$ Setelah & 30 & $2.93 \pm 1.639$ & & & \\
& & & & & \\
Jahe Asam & 30 & $5.23 \pm 1.924$ & 2.4 & 14.848 & 0.0001 \\
$\quad$ Sebelum & 30 & $2.80 \pm 1.690$ & & & \\
$\quad$ Setelah & & & & &
\end{tabular}

Paire t-test

Tabel 2. Perbedaan Efektivitas Minuman Kunyit Asam dan Jahe Asam Terhadap Penurunan Skala Nyeri Haid Primer

\begin{tabular}{lcccc}
\hline Kelompok & $\mathbf{n}$ & Mean dif & $\mathbf{t}$ & p-value \\
\hline Kunyit Asam-Jahe Asam & 60 & 0,133 & 0,310 & 0,0001
\end{tabular}

Independent $t$-test

Buah asam jawa juga memiliki kandungan tannins, saponins, sesquiterpenes, alkaloid, dan phlobotamins untuk mengurangi aktivitas sistem saraf. Telah dijelaskan sebelumnya bahwa kunyit memiliki efektivitas yang sama dengan ibuprofen dalam mengurangi nyeri. Secara umum ibuprofen dikenal sangat cepat dan efektif diserap setelah pemberian peroral.

Jahe mengandung gingerol yang mampu memblokir prostaglandin. Penelitian menunjukan bahwa jahe memiliki efektivitas yang sama dengan asam mefenamat dan ibuprofen dalam mengurangi rasa nyeri pada Nyeri Haid primer. Selain itu tidak ditemukan efek samping yang parah dari jahe (Corwin, 2009). Jahe memiliki efektivitas yang sama dengan ibuprofen dalam mengurangi nyeri. Secara umum ibuprofen dikenal sangat cepat dan efektif diserap setelah pemberian peroral. Puncak konsentrasi di dalam plasma sangat singkat yaitu antara 15 menit- 1 jam. Kerja dari ibuprofen pun sama dengan jahe yaitu dengan menghambat sintesis prostaglandin. Obat-obat/herbal yang sejenis dengan ibuprofen sangat mudah diabsorbsi oleh sistem gastrointestinal. Waktu paruh obat adalah waktu yang diperlukan obat untuk dimetabolisme. Waktu paruh ibuprofen relatif singkat (Corwin, 2009).

Terapi herbal kunyit asam lebih efektif dibandingkan dengan terapi herbal jahe dikarenakan pada kunyit asam memiliki aktivitas antioksidan yang lebih tinggi. Menurut Sejati (2002) dalam Astawan (2009) menyebutkan bahwa aktivitas antioksidan minuman kombinasi kunyit-asam jawa lebih baik daripada minuman asam jawa saja. Curcumine pada kunyit merupakan senyawa fenolik (senyawa essensial penangkap radikal bebas) yang memiliki kemampuan sebagai antioksidan. Aktivitas antioksidan yang dihasilkan cenderung meningkat dengan semakin banyaknya konsentrasi asam jawa yang ditambahkan. Kombinasi rempahrempah dan buah asam dapat meningkatkan resistensi antioksidan $\beta$ - karoten selama pemanasan. Penambahan asam jawa mampu menjaga kestabilan antioksidan yang terkandung dalam kunyit. Antioksidan dapat menstabilkan hormon di dalam tubuh, sehingga nyeri menstruasi berkurang (Pranata, 2014). 
R K Sugiharti, R I Sundari | Efektivitas Minuman Kunyit Asam dan Rempah Jahe Asam Terhadap Penurunan Skala Nyeri Haid Primer

\section{KESIMPULAN DAN SARAN}

Berdasarkan hasil penelitian yang telah dilakukan dapat disimpulkan bahwa ada perbedaan penurunan rata-rata skala nyeri haid primer sebelum dan sesudah intervensi pada kelompok minuman kunyit asam dan minuman rempah jahe asam. Minuman kunyit asam dan jahe asam dapat menurunkan nyeri haid primer. Akan tetapi, minuman kunyit asam lebih efektif dalam menurunkan nyeri haid primer pada remaja. Diharapkan pada perempuan yang mengalami nyeri haid primer untuk mengkonsumsi minuman kunyit asam untuk mengurangi nyeri haidnya.

\section{DAFTAR PUSTAKA}

Andira, Dita. (2012). Seluk Beluk Kesehatan Reproduksi Wanita: Jogjakarta: A Plus Books.

Astawan, M. (2009). Sehat dengan Hidangan Kacang dan Biji-Bijian. Bogor: Penebar Swadaya

Aulia. (2009). Kupas Tuntas Menstruasi . Yogyakarta: Millestone

Corwin E.J. (2009). Buku Saku Patofisiologi Corwin. Jakarta: Aditya Medika

Gilly A. (2009). Buku Ajar Kesehatan Reproduksi Wanita, Edisi 2. Jakarta: EGC.

Hatcher, H., Planalp, R., Cho, J., Torti, F. M., \& Torti, S. V. (2008). Curcumin: From ancient medicine to current clinical trials. Cellular and Molecular Life Sciences :

CMLS, 65(11), 1631-1652.

http://doi.org/10.1007/s00018-008-74 $52-4$

Kristiani, S.D.P, Kusumawati P. (2016). Perbedaan Penurunan Skor Skala Dismenore dengan Terapi Herbal Jahe dan Kunyit Asam pada Siswi Sekolah Menengah Kejuruan Muhammadiyah 2 Klaten Utara. Jurnal IImu Kesehatan STIKES Duta Gama Klaten. 8(2),1-21

Maulana, Heri D.J. (2009). Promosi Kesehatan. Jakarta : EGC

Morgan \& Hamilton. (2009). Obstetri dan Ginekologi: Panduan Praktik, Edisi 2. Jakarta: EGC.
Novia dan Puspitasari. (2008). Faktor Risiko Yang Mempengaruhi Dismenor Primer. The Indonesian Journal of Public Health. 4(3);96-103

Ortiz, M.I. (2010). Primary Dysmenorrhea Among Mexican Universty Students: Prevalence, Impact and Treatment. Eur J Obstet Gynecol Reprod Biol. 152(1),73-7. doi: 10.1016/j.ejogrb.2010.04.015.

Perry \& Potter. (2009). Fundamental Keperawatan Edisi 7. Jakarta: Salemba Medika.

Pranata, Tony. (2014). Herbal TOGA. Jakarta : Aksara Sukses

Saryono. (2011). Metodologi Penelitian Kesehatan. Yogyakarta: Mitra Cendikia Offset

Sugiyono. (2009). Metode Penelitian Kuantitatif Kualitatif dan R\&D. Bandung: Alfa Beta

Suharmiati dan Handayani, L. (2006). Cara Benar Meracik Obat. Jakarta: Agro Pustaka

Widyastuti, Yani, dkk. (2009). Kesehatan Reproduksi. Yogyakarta: Fitramaya 